\title{
The hidden intricacy of loot box design: A granular description of random reward mechanisms in games
}

\author{
Nick Ballou* \\ n.b.ballou@qmul.ac.uk \\ Queen Mary University of \\ London
}

\author{
Charles Gbadamosi \\ takashigbadamosi@gmail.com \\ DeepMind
}

\author{
David Zendle \\ david.zendle@york.ac.uk \\ University of York
}

This paper has been published in the Proceedings of DiGRA 2022 (in press) under an alternative title: LoBoF v0.1: Illustrating Loot Box Diversity in a Featural Model, with Emphasis on Player Behavior. We have updated the preprint text to match the published version but leave the original title for discoverability.

\begin{abstract}
While loot boxes are frequently treated as a monolithic feature of games by researchers and policymakers, loot box implementations are not uniform: the features of loot boxes vary widely from game to game in ways that may have important consequences for player spending and behavior. In this work, we attempt to illustrate the nuance present in loot box implementation in a preliminary Loot Box Features model (LoBoF v0.1). Using our lived experience, a qualitative coding exercise of 141 games, and consultation with an industry professional, we identify 32 categorical features of loot box-like mechanics that might be expected to influence player behavior or spending, which we group into 6 domains: point of purchase, pulling procedure, contents, audiovisual presentation, unpaid engagement, and social. We conclude with a discussion of potential implications of this wide variation in loot box design for researchers, regulators, and players.
\end{abstract}

\section{Keywords}

Loot boxes, game design, taxonomy, video games, monetization, gacha 


\section{INTRODUCTION}

Loot boxes may be defined as items in video games that may be bought for real-world money, but have randomized rewards. Loot boxes have become the target of heavy scrutiny, due at least in part to research suggesting that loot box spending is associated with greater severity of problem gambling in both adolescents (Kristiansen and Severin 2020; Zendle, Meyer, and Over 2019) and adults (Zendle and Cairns 2018). The prevalence of loot boxes has increased sharply since 2012, and they are frequently found in games rated acceptable for children as young as 3 years old (Zendle, Meyer, et al. 2020).

A 2018 editorial in Nature Human Behaviour noted the diversity of loot boxes, the lack of understanding of their diverse forms, and the need for researchers to begin "specifically investigating the impacts of different types of loot-box incarnations in video games" in order to "ensure that appropriate protections are put in place for minors and other vulnerable populations" ("Gaming or Gambling?" 2018). Loot boxes are, indeed, designed using a wide variety of forms. Within this paper we describe these differences in terms of features, by which we mean component aspects of design and implementation that may vary between different games' loot boxes. Unfortunately, previous investigations of loot box features have only scratched the surface of the aforementioned goal of usefully 'investigating the impacts of different types of loot-box incarnations'.

A handful of studies have attempted to generate a rigorous scheme for classifying loot boxes under various logical groupings. For example, Nielsen and Grabarczyk (2018) discusses monetized random rewards in relation to their economic embeddedness. The authors propose a $2 \times 2$ model based on whether (a) the resources required to obtain the loot box and (b) the rewards within it are isolated (not bearing any relationship to objects in the economy) vs embedded currencies (bearing relationship to other objects such that the value can be established in terms of other currencies), respectively. The authors go on to argue that random reward mechanics can only be considered gambling when both (a) and (b) are embedded. Within this system, any random reward which is obtained using either real-world money or a currency whose value can be understood in terms of real-world currency constitute a loot box; however, only loot boxes where (b) is also embedded would constitute gambling, and this distinction would be a function of the feature set of the loot box in question.

Sato et al. (2020) go into further depth, proposing a 6-level taxonomy based on testing of over 100 PC, mobile, and console games. They propose that random reward mechanisms can be categorized based on 1) how they are embedded in the real-world economy, 2) how the eligibility condition for a reward is triggered, 3) whether the odds for receiving a reward are openly displayed, 4) how rewards are selected, 5) how any randomized reward mechanism is audio-visually represented in a game, and 6) what kinds of rewards are granted.

The logical correctness of these groupings may be subject to debate: For example, with reference to Nielsen \& Grabarczyk (2018), Xiao (2020) notes that isolated currencies, whether used to purchase the loot box or that of the contents, may become embedded through third-party systems and extra-game transactions. More importantly, these two categorization schemes do not have the primary rationale of exhaustively attempting to define features of loot boxes that may importantly impact player behavior. By contrast, studies which do attempt to link player behavior to loot box features have tended to only investigate an arbitrary subset of features. For example, in Zendle, Cairns, et al. (2020) and Zendle, Meyer, \& Over (2019), researchers attempted to measure whether certain loot box features strengthened links between problem gambling and loot box spending. Candidate features included, for example, the ability of players to "cash out" loot box winnings, the display of in-game "near misses" when opening loot boxes, and whether loot box purchasing occurs using an in-game premium currency. However, in each case no comprehensive rationale was given for why these features might be the most important ways that the loot boxes currently on the market differ in terms of driving player behavior. Results of these studies are therefore limited by their partial definition of what important loot box features might be. 
Against this background, we believe that describing loot boxes in sufficiently granular terms to relate to the concrete decisions that designers make when implementing them and motivating purchases is of profound importance. Many loot box features are directly or indirectly implicated in a player's statistical maximum spend-the total amount of money that would be required, on average, to obtain a complete and/or maximum level collection in a game. Knowing this value is key, as "whales"-the small proportion of players with the largest financial outlays-make up a substantial portion of many games' total revenue. A recent study estimated that the top $1 \%$ of spenders in the Chinese Counter-Strike: Global Offensive market accounted for $26 \%$ of the game's revenue in that region (Zendle, Petrovskaya, and Wardle 2020).

Similarly, a comprehensive understanding of the features of loot boxes may be crucial for regulation. For example, the ability to "cash out" loot box contents for real-world money has already been used to distinguish between legal and illegal forms of loot boxes in countries like Belgium (Kansspelcommissie (Belgian Gaming Commission) 2018) and the Netherlands (Kanspelautoriteit (Netherlands Gambling Authority) 2018). Similarly, in 2012, Japan's Consumer Affairs Agency effectively banned complete, or "kompu" gacha mechanics in which players seek to obtain a complete set of relatively common items that are then combined or exchanged for a rare "grand prize" (Cermak 2020).

The focus of the present research is therefore to work toward developing a more complete range of loot box design features to allow for better identification of loot box mechanics and to facilitate informed decision-making both by researchers and consumers. We are interested in all meaningful differences in implementation-differences that might be expected to change player behavior or the cognitive/psychological effects of purchasing loot boxes.

It is paramount to note that any such attempt to taxonomize non-natural kinds is inherently contingent; there are infinite logical ways to divide loot boxes into categories, and our scheme is only meaningful insofar as it is useful for the above-identified pragmatic purpose of identifying features that may potentially have a meaningful impact on players (Nickerson, Varshney, and Muntermann 2013). This creates something of a chicken-and-egg situation, as the current evidence base-concerning both loot boxes and games more generally-is not sufficiently detailed to make strong claims about the impacts of individual features of games, but neither do we expect that features will be individually tested until they are identified. Given this, the taxonomy presented here should be viewed as a "version 0.1 " that attempts to capture differences that we presently hypothesize could plausibly make a difference for player behavior and experience. Accordingly, our hope is that future work will add and discard categories as arguments or evidence emerges to demonstrate that they are (ir)relevant with regard to the taxonomy's pragmatic purpose, and we invite our readers to participate in this process.

\section{METHOD}

Each of the three authors was assigned to independently generate a list of features (aspects of a loot box implementation that may vary across games), each with corresponding categories (discretized classifications that could be assigned to a given game's random reward mechanisms). As stated above, the minimum criterion for a proposed feature or category was that the researcher could clearly articulate how alterations in that feature might meaningfully affect player behavior.

Where possible, our intention was to justify hypothesized effects of each feature using previous literature or an existing theoretical framework. In our first iteration of the study, we attempted to ground all features of the taxonomy in a particular theoretical framework, dual-process theory (De Neys 2018). However, we quickly discovered that many features had easily describable routes through which they could meaningfully impact players, but that did not fit neatly into dual-process theory or any obvious alternatives. For many of these, there was no existing evidence at all upon which to base claims. 


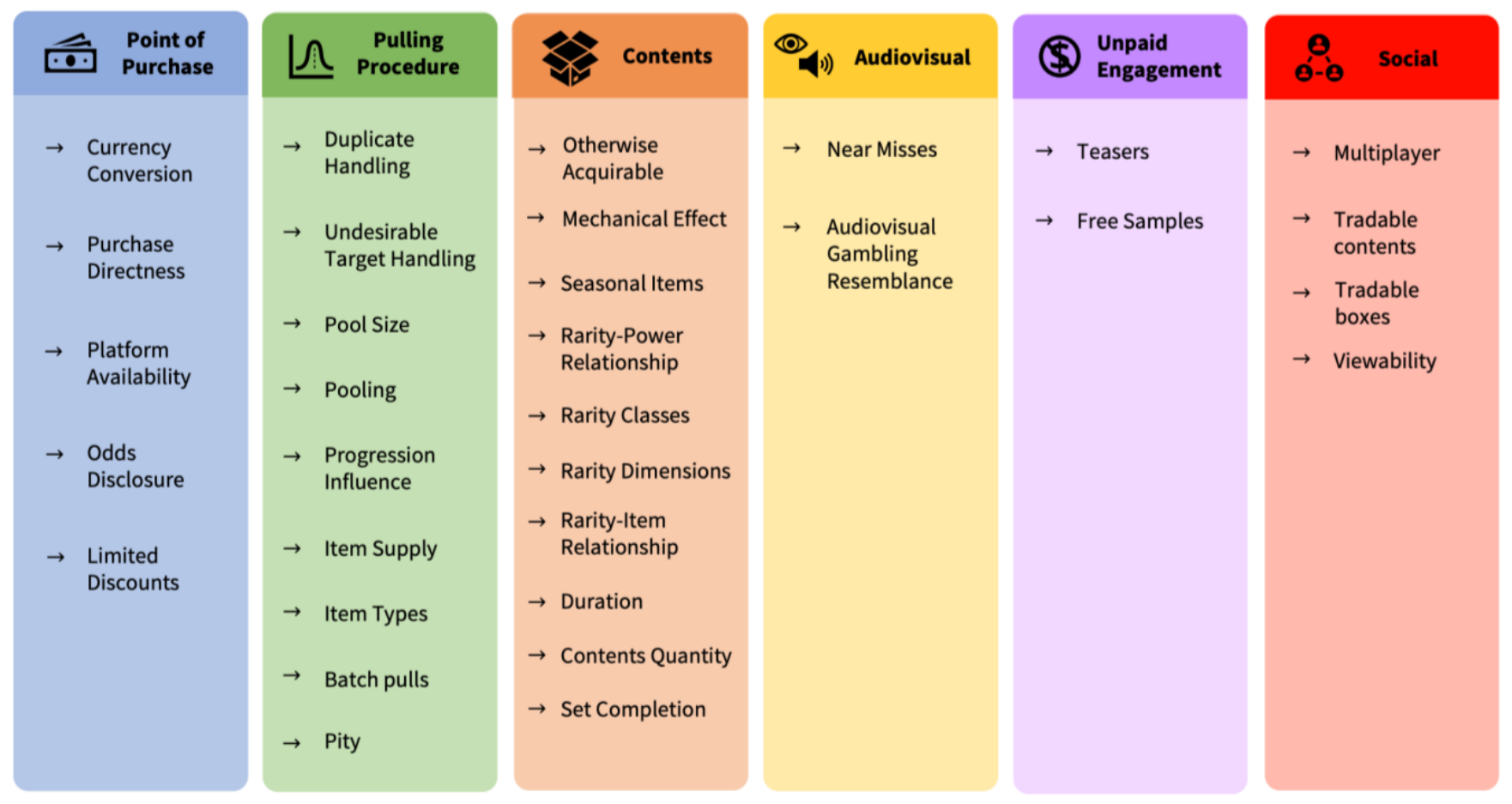

Figure 1: Summary of the Loot Box Features (LoBoF)

v0.1 model, grouped by similarity/relatedness into domains

Thus, we modified the task to embrace its inherent subjectivity; authors were instructed to reflect upon their own knowledge of games as a player, researcher, and (in the case of the second author) designer and developer. This method therefore aligns with a constructivist philosophy of science (Kukla 2000). Rather than supposing that the identified features are natural properties of the world, these are explicitly subjective divisions that we believe, based on their coherence with the data and our own expertise, may be useful both to highlight the abundant variation in this domain and to serve as a starting point for ongoing experimental work on how monetization design affects players.

To provoke new ideas during the construction of the taxonomy, authors supplemented their own intuitions with a versus coding exercise (Saldaña, 2016). Using existing data from two previous papers on loot boxes (Zendle, Meyer, and Ballou 2020; Zendle, Meyer, et al. 2020), two games at a time with loot box-like mechanics were randomly selected and juxtaposed. The data consisted of 141 Steam, iOS, and Android games (78 desktop and 63 mobile) that had identified in previous work as containing loot boxes, including brief qualitative descriptions of their implementation. Descriptions were generated based on English language (US or UK) versions of the games; it is important to note that games may contain different loot box options or mechanics in different languages/regions. Using this data combined with information from developer descriptions, forum discussions, video recordings on YouTube or Twitch.tv, and prior knowledge, authors coded each pair using " $X$ vs. $Y$ " statements highlighting differences between two games' loot box systems.

After each constructing separate feature and category lists, we then met for multiple rounds of iterative synthesis. We merged similar or identical features that appeared on multiple authors' lists and discussed game examples and rationales for why features that only appeared on one author's list had been identified, and why they might affect player behavior. Any features whose impact on players could not be clearly justified were removed. We proceeded with this process until we identified no more opportunities for simplification (4 rounds total).

In between the final two rounds of synthesis, we presented the draft list to an industry professional with more than a decade of experience in game monetization, free to play games, and loot box design. He provided feedback on the comprehensiveness of the feature list, identified design decisions from his lived experience that were not yet included, and helped speculate about the ways each feature might impact player behavior. This informed further changes to categorization, labeling, and rationale. 
The list of games with loot boxes, the individual feature lists, and each stage of the iterative synthesis are all available on the Open Science Framework (https://osf.io/emkyr).

\section{LOOT BOX FEATURES}

In total, 32 loot box features were identified which might be expected to influence player behavior or spending. We have grouped these features into six domains (summarized in Figure 1). For each feature, we include a brief description of why this feature may matter to player behavior and spending. This rationale may be derived from the lived game design experience of a member of the research team or our industry informant, previous psychological or behavioral economics research, or a combination.

Some features' categories are mutually exclusive; features where this is the case are marked with an asterisk. For other features, a game may contain any or all of the categories present. We use "items" as a generic term referring to all possible loot box contents; this may include characters, equipment, consumables, skins, cards, or any other representation of a virtual good that players may receive.

The design of loot boxes is inherently situated within the design of the game around them, and this context is often crucial to determining the value and potentially the effects of a loot box implementation. As a result, certain features in our model describe aspects of a single loot box mechanic in a game; for games that have multiple such mechanics, it is possible that each may fall into different categories. Other features relate to larger structural components of the game and would affect all loot boxes.

For space reasons-and because the goal of this paper is not to exhaustively detail features, but rather to provide an overview of the sheer breadth of loot box implementations-we do not discuss every category in depth here. Instead, results are presented largely in table form. We include the rationale for each feature's inclusion and hypothesized effect(s) within the tables and provide a brief general description of the domain with reference to certain particularly interesting or complicated features and categories. Longer written descriptions of each feature and category are available in the supplementary materials.

\section{Domain 1: Point of Purchase}

The Point of Purchase domain (Table 1) includes features related to the act of purchasing loot boxes. These features are often visible when visiting in-game shops. The high visibility of some of these features has made them an easier target for (self-)regulation: Odds Disclosure is mandated in China and self-regulated by the video games industry in other countries like the UK and US (Xiao, Henderson, and Newall 2021), and the UK Advertising Standards Authority recently identified Currency Conversion as potentially problematic when combined with "odd pricing" (mismatched increments of related purchases, e.g., virtual currency available in units of 50 credits, and items available in increments of 20 credits; Committee of Advertising Practice, 2021).

\begin{tabular}{|c|c|c|c|}
\hline Feature & Categories & Example & Rationale for Inclusion \\
\hline \multirow{3}{*}{$\begin{array}{l}\text { Currency } \\
\text { Conversion }\end{array}$} & $\begin{array}{l}\text { Purchase with real- } \\
\text { world currency }\end{array}$ & $\begin{array}{l}\text { War Chests } \\
\text { (Battalion 1944) }\end{array}$ & \multirow{3}{*}{$\begin{array}{l}\text { Premium currencies may both disguise the value of players' } \\
\text { outlays and exploit unwillingness to let small amounts of } \\
\text { residual premium currency go to waste (Lewis 2014), both } \\
\text { possibly resulting in greater spending. Players interpret the } \\
\text { value of, engage with, and spend virtual currency } \\
\text { differently than real-world currency (Wang and Mainwaring } \\
\text { 2008). }\end{array}$} \\
\hline & $\begin{array}{l}\text { Purchase indirectly } \\
\text { with virtual currency }\end{array}$ & $\begin{array}{l}\text { Crown Crates (Elder } \\
\text { Scrolls Online) }\end{array}$ & \\
\hline & $\begin{array}{l}\text { Purchase through one } \\
\text { or more exchanges of } \\
\text { virtual currencies }\end{array}$ & $\begin{array}{l}\text { Lockboxes } \\
\text { (Neverwinter) }\end{array}$ & \\
\hline \multirow{3}{*}{$\begin{array}{l}\text { Purchase } \\
\text { Directness }\end{array}$} & $\begin{array}{l}\text { Loot boxes are } \\
\text { specifically purchased }\end{array}$ & $\begin{array}{l}\text { Prize Boxes (Spiral } \\
\text { Knights) }\end{array}$ & \multirow{3}{*}{$\begin{array}{l}\text { When a player is only indirectly purchasing a loot box, they } \\
\text { may not hold interest in either the act of opening that loot } \\
\text { box or the rewards it contains. This kind of purchasing may } \\
\text { be unrelated to typical motivations and correlates of loot } \\
\text { box opening (Zendle, Meyer, and Over 2019). }\end{array}$} \\
\hline & $\begin{array}{l}\text { Loot boxes acquired } \\
\text { as part of a purchased } \\
\text { bundle }\end{array}$ & $\begin{array}{l}\text { Lucky Bags (Love } \\
\text { Nikki - Dress UP } \\
\text { Queen) }\end{array}$ & \\
\hline & $\begin{array}{l}\text { Players buy items that } \\
\text { periodically generate } \\
\text { loot boxes, but do not } \\
\text { buy loot boxes directly }\end{array}$ & $\begin{array}{l}\text { Super Incubator } \\
\text { (Pokemon GO) }\end{array}$ & \\
\hline
\end{tabular}




\begin{tabular}{|c|c|c|c|}
\hline & $\begin{array}{l}\text { Loot boxes } \\
\text { periodically given as } \\
\text { part of a battle pass } \\
\text { or/ paid subscription } \\
\text { service }\end{array}$ & $\begin{array}{l}\text { Daily Dice - Gold } \\
\text { Roll (Dungeons \& } \\
\text { Dragons Online, VIP } \\
\text { Subscription) }\end{array}$ & \\
\hline \multirow{2}{*}{$\begin{array}{l}\text { Platform } \\
\text { Availability* }\end{array}$} & Buy in-game only & $\begin{array}{l}\text { Sticker Packs (Board } \\
\text { Kings) }\end{array}$ & \multirow{2}{*}{$\begin{array}{l}\text { Players who can buy loot boxes outside of the game have } \\
\text { the opportunity to make purchases even when not playing } \\
\text { the game. This may increase total expenditure (Deans et al. } \\
\text { 2016) }\end{array}$} \\
\hline & Buy outside of game & $\begin{array}{l}\text { Mystery Boxes (Path } \\
\text { of Exile) }\end{array}$ & \\
\hline \multirow{2}{*}{$\begin{array}{l}\text { Odds } \\
\text { Disclosure* }\end{array}$} & Pre-disclosed odds & $\begin{array}{l}\text { Brawl Boxes (Brawl } \\
\text { Stars) }\end{array}$ & \multirow{2}{*}{$\begin{array}{l}\text { Disclosures may correct erroneous value beliefs, which are } \\
\text { especially common among problem gamblers (Monaghan } \\
\text { and Blaszczynski 2009). The impact of this effect may be } \\
\text { moderated by how odds are disclosed (Sprott, Hardesty, } \\
\text { and Miyazaki 1998). }\end{array}$} \\
\hline & No pre-disclosed odds & $\begin{array}{l}\text { Heka Chests } \\
\text { (Assassin's Creed } \\
\text { Origins) }\end{array}$ & \\
\hline \multirow{3}{*}{$\begin{array}{l}\text { Limited } \\
\text { Discounts }\end{array}$} & $\begin{array}{l}\text { Yes, loot boxes offered } \\
\text { at discounted rates for } \\
\text { limited periods of time }\end{array}$ & $\begin{array}{l}\text { Recruits (One Piece } \\
\text { Treasure Cruise) }\end{array}$ & \multirow{3}{*}{$\begin{array}{l}\text { Limited discounts may both motivate purchases and lead } \\
\text { players to assess the possibility of future purchases at a } \\
\text { higher price as a loss, with corresponding loss aversion } \\
\text { effects (Heidhues and Koszegi 2004) }\end{array}$} \\
\hline & $\begin{array}{l}\text { Yes, higher value loot } \\
\text { boxes or pools are } \\
\text { offered in limited } \\
\text { quantities. }\end{array}$ & $\begin{array}{l}\text { Platinum } \\
\text { Showcases } \\
\text { (Dragalia Lost) }\end{array}$ & \\
\hline & No limited discounts & $\begin{array}{l}\text { Expedition Packs } \\
\text { (Rise of the Tomb } \\
\text { Raider) }\end{array}$ & \\
\hline
\end{tabular}

Table 1: Point of Purchase features.

\section{Domain 2: Pulling Procedure}

The Pulling Procedure domain (Table 2 ) refers to features of the random procedure (i.e., the system that ultimately determines the items that players receive.) The features of the pulling procedure domain are those that are most intricately intertwined with the player's perceived value for money, as well as the maximum amount that any player may statistically spend. Three key intertwined features here are Item Supply, Duplicate Handling, and Undesirable Target Handling. Together, these three features largely govern the degree of "control" a player has when engaging with the loot box system to get particular items that they want and avoid others that they do not. By converted (analogous), we refer to a player's ability to exchange duplicates or undesired items into other items in the pool (i.e., items that the player could potentially have received from the loot box). Converted (orthogonal), on the other hand, refers to the exchange of loot box contents for items not part of the loot box pool. In both cases, games vary widely in their "exchange rate", or the number of duplicates/undesired items necessary to exchange for a desired one.

\begin{tabular}{|c|c|c|c|}
\hline Feature & Categories & Example & Rationale for Inclusion \\
\hline \multirow{4}{*}{$\begin{array}{l}\text { Duplicate } \\
\text { Handling* }\end{array}$} & $\begin{array}{l}\text { Cannot get } \\
\text { duplicates }\end{array}$ & Skins from Chests (Brawlhalla) & \multirow{4}{*}{$\begin{array}{l}\text { Allowing players to convert duplicate loot box } \\
\text { contents means that a player is guaranteed to } \\
\text { receive something from each loot box, even if this } \\
\text { reward is of less value than the fee of opening. This } \\
\text { may prompt more persistent spending, as in } \\
\text { gambling services where losses are "disguised as } \\
\text { wins" (Leino et al. 2016). }\end{array}$} \\
\hline & $\begin{array}{l}\text { Converted } \\
\text { (analogous) }\end{array}$ & $\begin{array}{l}\text { Cards in packs converted to } \\
\text { dust for crafting cards } \\
\text { (Hearthstone) }\end{array}$ & \\
\hline & $\begin{array}{l}\text { Converted } \\
\text { (orthogonal) }\end{array}$ & $\begin{array}{l}\text { Summons converted to } \\
\text { Eldwater for promoting } \\
\text { characters (Dragalia Lost) }\end{array}$ & \\
\hline & Stacking & Cards in Chests (Clash Royale) & \\
\hline \multirow{3}{*}{$\begin{array}{l}\text { Undesirable } \\
\text { Target } \\
\text { Handling }\end{array}$} & No system & Skins from Chests (SMITE) & \multirow{3}{*}{$\begin{array}{l}\text { Similar to Duplicate Handling, games with effective } \\
\text { undesirable target handling systems will convey a } \\
\text { higher value "floor" for each pull, and also may be } \\
\text { perceived by players as offering a greater sense of } \\
\text { autonomy (Przybylski, Rigby, and Ryan 2010). }\end{array}$} \\
\hline & $\begin{array}{l}\text { Player } \\
\text { choice/reroll }\end{array}$ & $\begin{array}{l}\text { Players choose up to } 5 \\
\text { randomly-displayed stones to } \\
\text { summon heroes of particular } \\
\text { types (Fire Emblem Heroes) }\end{array}$ & \\
\hline & $\begin{array}{l}\text { Converted } \\
\text { (analogous) }\end{array}$ & $\begin{array}{l}\text { Cards in packs converted } \\
\text { (liquified) to vials for crafting } \\
\text { cards (Shadowverse) }\end{array}$ & \\
\hline
\end{tabular}




\begin{tabular}{|c|c|c|c|}
\hline & $\begin{array}{l}\text { Converted } \\
\text { (orthogonal) }\end{array}$ & $\begin{array}{l}\text { Champions from summons } \\
\text { converted into experience for } \\
\text { other champions (RAID: } \\
\text { Shadow Legends) }\end{array}$ & \\
\hline \multirow{3}{*}{ Pool Size* } & $10 \mathrm{~s}$ & $\begin{array}{l}\text { Outbreak Packs (Tom Clancy's } \\
\text { Rainbow Six Siege, } 2018 \text { event) }\end{array}$ & \multirow{3}{*}{$\begin{array}{l}\text { All else equal, the larger the pool size, the greater an } \\
\text { amount that a player must spend before acquiring all } \\
\text { loot box contents. }\end{array}$} \\
\hline & $100 \mathrm{~s}$ & Loot Booth (Deceit) & \\
\hline & $1000 \mathrm{~s}$ & $\begin{array}{l}\text { Booster Packs (Pokemon TCG } \\
\text { Online) }\end{array}$ & \\
\hline \multirow{4}{*}{ Pooling* } & $\begin{array}{l}\text { Different rates, } \\
\text { same pool }\end{array}$ & $\begin{array}{l}\text { Small/Medium/Large Chests } \\
\text { (Pewdiepie's Pixelings) }\end{array}$ & \multirow{4}{*}{$\begin{array}{l}\text { Certain types of pooling give players greater } \\
\text { perceived control over "targeting" particular items. } \\
\text { This perception of control may lead to increased } \\
\text { spending (Dixon 2000). When different pools with } \\
\text { different reward schemes are presented, both state } \\
\text { and trait factors may influence suboptimal selection } \\
\text { of a specific pool (Suhr and Tsanadis 2007). }\end{array}$} \\
\hline & $\begin{array}{l}\text { Mutually exclusive } \\
\text { pools }\end{array}$ & Booster Packs (Magic Duels) & \\
\hline & Strict subset pools & $\begin{array}{l}\text { Normal vs Expert Equipment } \\
\text { Cases (Dirty Bomb) }\end{array}$ & \\
\hline & No pooling & Airdrops (Z1 Battle Royale) & \\
\hline \multirow{2}{*}{$\begin{array}{l}\text { Progression } \\
\text { Influence* }\end{array}$} & $\begin{array}{l}\text { Player } \\
\text { progression } \\
\text { changes } \\
\text { contents/odds }\end{array}$ & Chests (Clash Royale) & \multirow{2}{*}{$\begin{array}{l}\text { Where progression changes contents or odds, players } \\
\text { may withhold spending until they have progressed } \\
\text { further into the game or spend more heavily after } \\
\text { reaching a point at which a desired item enters the } \\
\text { pool. }\end{array}$} \\
\hline & $\begin{array}{l}\text { Player } \\
\text { progression does } \\
\text { not change } \\
\text { content/odds }\end{array}$ & Lucky Roulette (Guns of Glory) & \\
\hline \multirow[b]{2}{*}{ Item Types } & Single & $\begin{array}{l}\text { Heroes from Summons } \\
\text { (Empires \& Puzzles) }\end{array}$ & \multirow{2}{*}{$\begin{array}{l}\text { Item types can compound the effect of rarity when } \\
\text { pulling-if a desirable item type is only } \mathrm{X} \% \text { likely to } \\
\text { be found in the loot box, and the player is only } \\
\text { interested in Y\% of that item type, they end up with } \\
\text { only a X\%*Y\% chance of a desired outcome. }\end{array}$} \\
\hline & Multiple & $\begin{array}{l}\text { Resources, Tomes, \& } \\
\text { Commanders from Chests } \\
\text { (Rise of Kingdoms) }\end{array}$ & \\
\hline \multirow{4}{*}{ Item Supply } & Finite per player & $\begin{array}{l}\text { Holo-day Bash Packs (Apex } \\
\text { Legends) }\end{array}$ & \multirow{4}{*}{$\begin{array}{l}\text { Although closely connected with Duplicate } \\
\text { Handling, rather than determining what happens if a } \\
\text { duplicate is received, Item Supply instead } \\
\text { determines how the likelihood of receiving a } \\
\text { duplicate changes over time. }\end{array}$} \\
\hline & Resettable boxes & $\begin{array}{l}\text { Card Boxes (Yu-Gi-Oh! Duel } \\
\text { Links) }\end{array}$ & \\
\hline & $\begin{array}{l}\text { Semi-finite / Finite } \\
\text { sub-collections }\end{array}$ & Cards in Packs (Hearthstone) & \\
\hline & Infinite & $\begin{array}{l}\text { Cards in Packs (Gods } \\
\text { Unchained) }\end{array}$ & \\
\hline \multirow{3}{*}{ Batch pulls* } & Yes, incentivized & $\begin{array}{l}\text { Multi-summons (Dragon Ball Z: } \\
\text { Dokkan Battle) }\end{array}$ & \multirow{3}{*}{$\begin{array}{l}\text { Giving multiple simultaneous payouts in gambling } \\
\text { (e.g. multi-line slots) may provide a more immersive } \\
\text { experience and higher rates of betting (Murch and } \\
\text { Clark 2019); batch pulls may similarly encourage } \\
\text { spending in greater amounts at a more rapid pace. }\end{array}$} \\
\hline & Yes, no incentive & Chests (Lords Mobile) & \\
\hline & Not possible & Chests (Hustle Castle) & \\
\hline \multirow{4}{*}{ Pity } & Pull threshold & Packs (Apex Legends) & \multirow{4}{*}{$\begin{array}{l}\text { Gambling machines which deterministically } \\
\text { guarantee an eventual payout may lead to higher } \\
\text { spending as individuals feel closer to achieving a } \\
\text { reward; pity mechanics may operate in a similar } \\
\text { manner (Li et al. 2016). }\end{array}$} \\
\hline & Pull scaling & $\begin{array}{l}\text { Enhancement Rolls (Black } \\
\text { Desert Online) }\end{array}$ & \\
\hline & Pull prize & Superchest (War Robots) & \\
\hline & None & Packs (Eternal) & \\
\hline
\end{tabular}

Table 2: Pulling Procedure features

\section{Domain 3: Contents}

The Contents domain (Table 3 ) refers to qualities of the items received from the loot box. Whereas the Pulling Procedure domain described features of the algorithms that distribute rewards to players (and in some cases, convert them to other rewards), Contents features refer to the in-game systems that determine the (perceived) value of the items. This includes particular attention to the rarity systems that govern the range of possible outcomes. 


\begin{tabular}{|c|c|c|c|}
\hline \multirow{3}{*}{$\begin{array}{l}\text { Otherwise } \\
\text { Acquirable }\end{array}$} & $\begin{array}{l}\text { Yes, through } \\
\text { direct purchase }\end{array}$ & $\begin{array}{l}\text { Wildcards from Packs } \\
\text { (Legends of Runeterra) }\end{array}$ & \multirow{3}{*}{$\begin{array}{l}\text { The ability to purchase items directly establishes a real- } \\
\text { world valuation of the loot box contents. The size of this } \\
\text { valuation may increase or decrease the persistence and } \\
\text { volume of loot box spending to obtain that item. } \\
\text { Conversely, offering items scarcely in loot boxes may } \\
\text { convey to players a high valuation of that item, increasing } \\
\text { the likelihood of them purchasing the item later through a } \\
\text { comparatively appealing direct-buy transaction. }\end{array}$} \\
\hline & $\begin{array}{l}\text { Yes, without } \\
\text { purchase }\end{array}$ & $\begin{array}{l}\text { Cosmetics from Treasures } \\
\text { (Dota } 2)\end{array}$ & \\
\hline & $\begin{array}{l}\text { Not otherwise } \\
\text { acquirable }\end{array}$ & $\begin{array}{l}\text { Adventurers and Dragons } \\
\text { from Summons (Dragalia } \\
\text { Lost) }\end{array}$ & \\
\hline \multirow[b]{3}{*}{$\begin{array}{l}\text { Mechanical } \\
\text { Effect }\end{array}$} & $\begin{array}{l}\text { Yes, gameplay- } \\
\text { altering }\end{array}$ & $\begin{array}{l}\text { Implant Packs (PlanetSide } \\
\text { 2) }\end{array}$ & \multirow{3}{*}{$\begin{array}{l}\text { In comparison to cosmetic contents, which may only be } \\
\text { valued by a certain portion of the player base (Tondello et } \\
\text { al. 2019), the potential for greater spenders to have a } \\
\text { greater chance of success means that contents with } \\
\text { mechanical effects may be desirable for a wider portion of a } \\
\text { game's players. } \\
\text { Mechanical effects, which in their most extreme form may } \\
\text { be labeled "pay to win", are among the most controversial } \\
\text { features in gaming communities (see e.g., Tregel et al. 2020) }\end{array}$} \\
\hline & Mixed & Player packs (NBA 2K21) & \\
\hline & No, cosmetic & $\begin{array}{l}\text { Treasure Chests } \\
\text { (Paladins) }\end{array}$ & \\
\hline \multirow{2}{*}{$\begin{array}{l}\text { Seasonal } \\
\text { Items }\end{array}$} & $\begin{array}{l}\text { Yes, seasonal } \\
\text { items present }\end{array}$ & $\begin{array}{l}\text { Boxes (Riders of Icarus), } \\
\text { Crates (Warface: } \\
\text { Breakout) }\end{array}$ & \multirow{2}{*}{$\begin{array}{l}\text { When present, the scarcity associated with seasonal items } \\
\text { and perceived threat of missed opportunities may motivate } \\
\text { purchasing (Hamari and Lehdonvirta 2010). }\end{array}$} \\
\hline & $\begin{array}{l}\text { No seasonal } \\
\text { items }\end{array}$ & $\begin{array}{l}\text { Treasure Shrine (Solitaire } \\
\text { Tripeaks: Classic Patience } \\
\text { Card Game) }\end{array}$ & \\
\hline \multirow{3}{*}{$\begin{array}{l}\text { Rarity-Power } \\
\text { Relationship }\end{array}$} & Tight & $\begin{array}{l}\text { Summons (Final Fantasy } \\
\text { Brave Exvius) }\end{array}$ & \multirow{3}{*}{$\begin{array}{l}\text { Where rarity is connected to power, there is a greater } \\
\text { advantage for high-spending players and a greater incentive } \\
\text { to spend more to acquire the item (Ham 2010); if the items } \\
\text { are not otherwise acquirable, greater spending would come } \\
\text { in the form of greater loot box opening. }\end{array}$} \\
\hline & Loose & $\begin{array}{l}\text { Common/Rare/Epic } \\
\text { /Legendary Cards (Gwent) }\end{array}$ & \\
\hline & No relationship & Crates (PUBG MOBILE) & \\
\hline \multirow{3}{*}{ Rarity Classes } & Boolean & $\begin{array}{l}\text { Normal/Gold Cards from } \\
\text { Packs (Kards) }\end{array}$ & \multirow{3}{*}{$\begin{array}{l}\text { Less granular rarity classes may have fewer, but more } \\
\text { impactful "big wins"; more granular ones may lead to } \\
\text { perceptions of success despite not receiving the rarest } \\
\text { items. }\end{array}$} \\
\hline & Ordinal & $\begin{array}{l}\text { 1-5 Star Monsters from } \\
\text { Summons (Summoners } \\
\text { War) }\end{array}$ & \\
\hline & Continuous & $\begin{array}{l}\text { Skin Wear Rating }(0.00- \\
1.00) \text { (Counter-Strike: } \\
\text { Global Offensive) }\end{array}$ & \\
\hline \multirow{2}{*}{$\begin{array}{l}\text { Rarity } \\
\text { Dimensions }\end{array}$} & Single & $\begin{array}{l}\text { Hero Star Ratings from } \\
\text { Summons (Idle Heroes) }\end{array}$ & \multirow{2}{*}{$\begin{array}{l}\text { When there exist rare and desirable versions of rare and } \\
\text { desirable items, the odds of achieving both simultaneously } \\
\text { drop precipitously, potentially leading to increases in } \\
\text { volume and persistence of spending among players who are } \\
\text { especially interested in a small subset of items. }\end{array}$} \\
\hline & Multiple & $\begin{array}{l}\text { Card Rarity and Premium } \\
\text { Status (Eternal) }\end{array}$ & \\
\hline \multirow[b]{2}{*}{$\begin{array}{l}\text { Rarity-Item } \\
\text { Relationship }\end{array}$} & $\begin{array}{l}\text { Particular items } \\
\text { have one } \\
\text { possible rarity }\end{array}$ & $\begin{array}{l}\text { Cosmetics in Crates } \\
\text { (Killing Floor 2) }\end{array}$ & \multirow[b]{2}{*}{ Can have an effect similar to adding a Rarity Dimension. } \\
\hline & $\begin{array}{l}\text { Particular items } \\
\text { have many } \\
\text { possible rarities }\end{array}$ & $\begin{array}{l}\text { Characters from } \\
\text { Summons (Tokyo } \\
\text { Afterschool Summoners, } \\
\text { aka Housamo) }\end{array}$ & \\
\hline \multirow{3}{*}{ Duration } & $\begin{array}{l}\text { Permanent, } \\
\text { perpetually } \\
\text { valuable }\end{array}$ & $\begin{array}{l}\text { Skins from Mann Co. } \\
\text { Supply Crates (Team } \\
\text { Fortress 2) }\end{array}$ & \multirow{3}{*}{$\begin{array}{l}\text { If loot box contents are not perpetually valuable, the } \\
\text { maximum spend is essentially uncapped; if the player wants } \\
\text { to consistently have a complete or sufficiently powerful } \\
\text { collection, they will have to continue spending for as long as } \\
\text { they are engaged with the game. }\end{array}$} \\
\hline & $\begin{array}{l}\text { Permanent, } \\
\text { value } \\
\text { deteriorates }\end{array}$ & $\begin{array}{l}\text { Cards rotating out of } \\
\text { Rotation Mode } \\
\text { (Shadowverse) }\end{array}$ & \\
\hline & Temporary & $\begin{array}{l}\text { Weapons from Joker } \\
\text { Mystery Boxes (APB: } \\
\text { Reloaded) }\end{array}$ & \\
\hline
\end{tabular}




\begin{tabular}{|c|c|c|c|}
\hline & Consumable & $\begin{array}{l}\text { Magic Potions from } \\
\text { Chests (Disney Magic } \\
\text { Kingdoms) }\end{array}$ & \\
\hline \multirow{3}{*}{$\begin{array}{l}\text { Contents } \\
\text { Quantity }\end{array}$} & Single Item & Treasures (Dota 2) & \multirow{3}{*}{$\begin{array}{l}\text { As with Batch Pulls, the release of multiple simultaneous } \\
\text { payouts may increase persistence and volume of spending. }\end{array}$} \\
\hline & Variable items & $\begin{array}{l}\text { Silver Chests (Clash } \\
\text { Royale) }\end{array}$ & \\
\hline & $\begin{array}{l}\text { Multiple items } \\
\text { (fixed) }\end{array}$ & $\begin{array}{l}\text { Lunchboxes (Fallout } \\
\text { Shelter) }\end{array}$ & \\
\hline \multirow{3}{*}{$\begin{array}{l}\text { Set } \\
\text { Completion }\end{array}$} & $\begin{array}{l}\text { Completing set } \\
\text { awards } \\
\text { exclusive item }\end{array}$ & Hiding Fish (AbyssRium) & \multirow{3}{*}{$\begin{array}{l}\text { Set completion features may motivate players based on the } \\
\text { psychological satisfaction of a complete collection, but also } \\
\text { can exploit the appearance of linear progress despite the } \\
\text { odds of getting each missing item decreasing with each } \\
\text { additional item from the set that the player obtains (Josef } \\
\text { and Tanaka 2017). Under the term "kompu gacha", such } \\
\text { mechanics are banned in Japan (Cermak 2020). }\end{array}$} \\
\hline & $\begin{array}{l}\text { Completing set } \\
\text { enhances } \\
\text { existing items }\end{array}$ & Bonds (Langrisser) & \\
\hline & $\begin{array}{l}\text { No bonus for } \\
\text { completing set }\end{array}$ & $\begin{array}{l}\text { Badge Packs (Game of } \\
\text { Sultans) }\end{array}$ & \\
\hline
\end{tabular}

Table 3: Contents features

\section{Domain 4: Audiovisual}

The Audiovisual domain (Table 4) consists of two features relating to the presentation (i.e., animations) of the loot box opening process. Specifically, both assess ways that loot boxes in games may use metaphors and mechanics found in traditional non-virtual gambling, like Near Misses on a roulette wheel, or a slot machine-like system for opening loot boxes in-game.

\begin{tabular}{|c|c|c|c|}
\hline Feature & Categories & Example & Rationale for Inclusion \\
\hline \multirow[b]{2}{*}{ Near misses* } & $\begin{array}{l}\text { Yes, near } \\
\text { misses shown }\end{array}$ & $\begin{array}{l}\text { Crystals (Marvel } \\
\text { Contest of } \\
\text { Champions) }\end{array}$ & \multirow{2}{*}{$\begin{array}{l}\text { Near misses in the gambling domain are associated with } \\
\text { increased persistence (Kassinove and Schare 2001), and this effect } \\
\text { may be moderated by problem gambling severity (Chase and } \\
\text { Clark 2010). Similar effects may occur in the loot box domain } \\
\text { when a desired outcome is shown to be "almost" achieved (e.g. a } \\
\text { rare item is displayed on a spinning wheel but is missed and a less } \\
\text { rare item is obtained). }\end{array}$} \\
\hline & No near misses & $\begin{array}{l}\text { Chests (Golf } \\
\text { Clash) }\end{array}$ & \\
\hline \multirow{2}{*}{$\begin{array}{l}\text { Audiovisual } \\
\text { Gambling } \\
\text { Resemblance* }\end{array}$} & $\begin{array}{l}\text { Resembles } \\
\text { traditional form } \\
\text { of gambling }\end{array}$ & $\begin{array}{l}\text { Roulette } \\
\text { metaphor at } \\
\text { Power Tower } \\
\text { (Minion Masters) }\end{array}$ & \multirow{2}{*}{$\begin{array}{l}\text { Resemblances to traditional gambling may trigger cue reactivity } \\
\text { among existing problem gamblers (Starcke et al. 2018) the effect } \\
\text { of triggering players' existing associations with casino games and } \\
\text { familiarizing players with gambling over time. }\end{array}$} \\
\hline & $\begin{array}{l}\text { Does not } \\
\text { resemble } \\
\text { traditional form } \\
\text { of gambling }\end{array}$ & $\begin{array}{l}\text { Premium Packs } \\
\text { (For Honor) }\end{array}$ & \\
\hline
\end{tabular}

Table 4: Audiovisual features

\section{Domain 5: Unpaid Engagement}

The Unpaid Engagement domain (Table 5) describes ways that game designers can encourage or compel players to interact with the loot box system. This is done by providing players with loot box-like items earned for free throughout gameplay, in some cases with certain limitations, such as a limited inventory for Teasers $>$ rushable timer.

\begin{tabular}{|c|l|l|l|}
\hline \multicolumn{1}{|c|}{ Feature } & \multicolumn{1}{|c|}{ Categories } & \multicolumn{1}{c|}{ Example } \\
& $\begin{array}{l}\text { Locked loot boxes } \\
\text { provided, currency } \\
\text { required to open }\end{array}$ & $\begin{array}{l}\text { Weapons Crates (Counter- } \\
\text { Strike: Global Offensive), } \\
\text { Mystery Tool Boxes (Hay } \\
\text { Day) }\end{array}$ & $\begin{array}{l}\text { With teasers, players must choose to either pay to open } \\
\text { the loot boxes they already have, wait enough time, or } \\
\text { forego the rewards they would get from continued } \\
\text { play-this in turn may induce loss aversion and provoke } \\
\text { spending. Teasers may also be understood in the } \\
\text { context of the endowment effect (Madigan 2016; Thaler } \\
1980) .\end{array}$ \\
\cline { 2 - 4 } & $\begin{array}{l}\text { Locked loot boxes } \\
\text { provided, rushable } \\
\text { timer }\end{array}$ & Chests (Clash Royale) & \\
\hline
\end{tabular}




\begin{tabular}{|c|c|c|c|}
\hline & No teasers & Fortune Wheel (SoulWorker) & \\
\hline \multirow{4}{*}{$\begin{array}{l}\text { Free } \\
\text { Samples }\end{array}$} & $\begin{array}{l}\text { Free identical loot } \\
\text { boxes }\end{array}$ & War Chests (Battalion 1944) & \multirow{4}{*}{$\begin{array}{l}\text { Exposure to loot boxes through free samples may } \\
\text { increase familiarity with the mechanic, expose players } \\
\text { to loot boxes even when payments on their account are } \\
\text { restricted, and create positive associations when a free } \\
\text { sample yields a "big win". Free samples, particularly } \\
\text { identical and analogous ones, may act similarly to } \\
\text { gambling "practice sites" (McBride and Derevensky } \\
\text { 2009). }\end{array}$} \\
\hline & $\begin{array}{l}\text { Free analogous loot } \\
\text { boxes }\end{array}$ & $\begin{array}{l}\text { Basic Chest (Injustice } 2 \\
\text { Mobile) }\end{array}$ & \\
\hline & $\begin{array}{l}\text { Free premium } \\
\text { currency }\end{array}$ & $\begin{array}{l}\text { Rubies to buy Gilds (Clicker } \\
\text { Heroes) }\end{array}$ & \\
\hline & $\begin{array}{l}\text { None, all loot boxes } \\
\text { require payment }\end{array}$ & $\begin{array}{l}\text { Goodie Boxes (The Sims 3, } \\
\text { circa 2016) }\end{array}$ & \\
\hline
\end{tabular}

Table 5: Unpaid Engagement features

\section{Domain 6: Social}

The Social domain (Table 6) describes four features related to whether opening loot boxes can affect, or be affected by, other players. In the case of Tradable Contents, the involvement of other players effectively created a market economy in which players can negotiate the value of their boxes or virtual goods for extragame, real-world currency (i.e., can "cash out" their winnings) - sometimes even despite clear prohibitions on this from the developer (as seen with Tradable Contents > developer-restricted open economy). The presence of Tradable Contents has already been used to differentiate legal and non-legal forms of loot boxes in Belgium (Kansspelcommissie [Belgian Gaming Commission] 2018) and the Netherlands (Kanspelautoriteit [Netherlands Gambling Authority] 2018).

\begin{tabular}{|c|c|c|c|}
\hline Feature & Categories & Example & Rationale for Inclusion \\
\hline \multirow{3}{*}{ Multiplayer } & $\begin{array}{l}\text { Contents can be } \\
\text { used in } \\
\text { competitive } \\
\text { multiplayer }\end{array}$ & $\begin{array}{l}\text { Chests (Monster } \\
\text { Legends) }\end{array}$ & \multirow{3}{*}{$\begin{array}{l}\text { Competitive multiplayer modes might inspire players to "even } \\
\text { the playing field" after losing against a more powerful opponent, } \\
\text { or to exert a sense of domination over weaker, lower spending } \\
\text { players (Yee 2006) - see also Mechanical Effect. }\end{array}$} \\
\hline & $\begin{array}{l}\text { Contents can be } \\
\text { used in } \\
\text { cooperative } \\
\text { multiplayer }\end{array}$ & $\begin{array}{l}\text { Time Capsules (DC } \\
\text { Universe Online) }\end{array}$ & \\
\hline & $\begin{array}{l}\text { Contents cannot } \\
\text { be used in } \\
\text { multiplayer }\end{array}$ & $\begin{array}{l}\text { Breach Packs (Deus } \\
\text { Ex: Mankind Divided) }\end{array}$ & \\
\hline \multirow{3}{*}{$\begin{array}{l}\text { Tradable } \\
\text { Contents* }\end{array}$} & $\begin{array}{l}\text { Developer- } \\
\text { sanctioned open } \\
\text { economy }\end{array}$ & $\begin{array}{l}\text { Card Market (Gods } \\
\text { Unchained) }\end{array}$ & \multirow{3}{*}{$\begin{array}{l}\text { By virtue of allowing players to directly profit from rare and } \\
\text { valuable items, tradable contents more closely resemble } \\
\text { traditional forms of gambling (Xiao 2020). }\end{array}$} \\
\hline & $\begin{array}{l}\text { Developer- } \\
\text { restricted open } \\
\text { economy }\end{array}$ & $\begin{array}{l}\text { Prohibition on coin } \\
\text { transfer (FIFA } 22 \\
\text { Ultimate Team) }\end{array}$ & \\
\hline & Closed economy & $\begin{array}{l}\text { Recruitment (Last } \\
\text { Shelter: Survival) }\end{array}$ & \\
\hline \multirow{2}{*}{$\begin{array}{l}\text { Tradable } \\
\text { Boxes* }\end{array}$} & $\begin{array}{l}\text { Unopened loot } \\
\text { boxes can be } \\
\text { traded }\end{array}$ & $\begin{array}{l}\text { Masquerpet Treasure } \\
\text { Box (Flyff [Fly for } \\
\text { Fun]) }\end{array}$ & \multirow{2}{*}{$\begin{array}{l}\text { Tradable loot boxes allow the player base to determine the } \\
\text { market value of a loot box, rather than the developer, potentially } \\
\text { leading to perceptions of fairer value. Where such trading is } \\
\text { possible outside of controlled marketplaces, this also allows for } \\
\text { players to exchange loot box contents with payment other than } \\
\text { the game's currencies, potentially leading to wider engagement. }\end{array}$} \\
\hline & $\begin{array}{l}\text { Unopened loot } \\
\text { boxes cannot be } \\
\text { traded }\end{array}$ & Crates (CSR Racing 2) & \\
\hline \multirow{2}{*}{ Viewability } & $\begin{array}{l}\text { Loot box } \\
\text { openings can be } \\
\text { observed by } \\
\text { other players }\end{array}$ & $\begin{array}{l}\text { Opening Supply } \\
\text { Drops in Public } \\
\text { Headquarters Zone } \\
\text { (Call of Duty: WWII) }\end{array}$ & \multirow{2}{*}{$\begin{array}{l}\text { Viewable loot box openings may act as a form of social proof, and } \\
\text { lead gamers to engage in imitative spending (Hedström and } \\
\text { Swedberg 1998); the conspicuousness of viewable openings may } \\
\text { provoke spending amongst gamers due to a desire for visible } \\
\text { social status via conspicuous consumption (Brock and Johnson } \\
\text { 2020; Veblen 1899). }\end{array}$} \\
\hline & $\begin{array}{l}\text { Selected loot box } \\
\text { contents } \\
\text { displayed to } \\
\text { other players }\end{array}$ & $\begin{array}{l}\text { Summon } \\
\text { Notifications (Epic } \\
\text { Seven) }\end{array}$ & \\
\hline
\end{tabular}




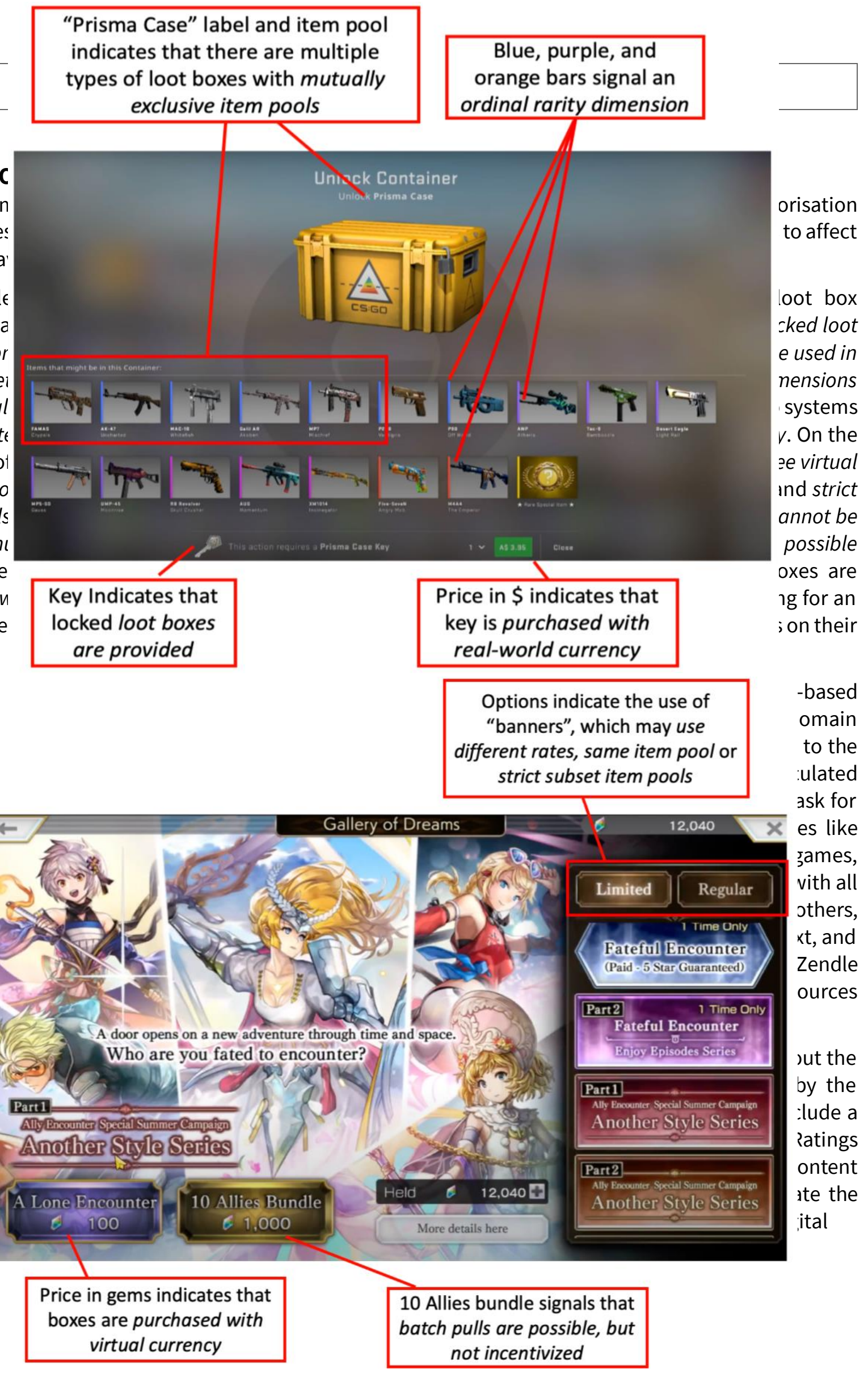

Figure 2: Comparison of features from Counter-Strike: Global Offensive (top) and Another Eden (bottom). Many features are not visually represented either on the purchase screen or elsewhere in-game and are thus not tagged on the images here. 
store label description is necessarily highly limited, the emergence of sites like MICROTRANSACTION.ZONE and Common Sense Media's game reviews (Common Sense Media, n.d.) suggests that there may be demand from players and parents to understand the content, and specifically the monetization structure, of games more thoroughly.

This work may also be of use for designers who use, or are considering using, random reward mechanics in their games in a responsible manner. Certain key behaviors of interest may be describable in terms of the LoBoF model. For example, game designers sometimes target particular quantities and frequency of loot box engagement. In some games it may be more typical or desirable to open a large amount of loot boxes infrequently (say, with the release of a new expansion), while other games encourage opening a single loot box every day. These are higher level design goals that may be operationalized through a combination of features like Teasers, Pool Size, Mechanical Effect, and Batch Pulls. Such patterns would likely have different effects on habit formation, exposure prevalence, mental models of value, and player experience; a player who opens one loot box per day with a $1 \%$ chance of a rare item might only report one positive experience every three months, while another player who opens 100 loot boxes on one day might associate loot box openings with more consistent positive outcomes. While they remain controversial, loot box mechanics remain a conspicuous and common feature of the gaming landscape, and we call on developers to both reflect carefully on which features they implement as well as guard against possible negative outcomes for players where possible.

The model presented here largely incorporates and expands upon previous attempts to categorize loot boxes. We address Nielsen and Grabarczyk's (2018) notion of reward embeddedness in Trading (nonembedded currencies used to purchase random rewards do not fall under the definition of loot boxes here). We add nuance to this by differentiating the developer-sanctioned open economy category to describe loot boxes that purport to have isolated contents, but whose design allows for those contents to become embedded (Xiao, 2020). ${ }^{1}$ King et al.'s (2012) distinction between standard and non-standard gambling simulation, where applicable to loot boxes, is found in the Gambling Game Resemblance feature. All of the features discussed by Zendle, Meyer, and Over (2019) are included and have been expanded upon in the current model, with the exception of reinvestment (loot boxes that yield the same currency used to purchase them), as no games in our data were found to implement this. ${ }^{2}$

The previous most comprehensive attempt to taxonomize loot boxes is that of Sato et al. (2020), which overlaps substantially with our work. For example, what they describe as a Trigger Condition is partly covered by Currency Conversion, and their sub-types of random procedure are covered by Duplicate Handling, Undesirable Target Handling, Batch Pulls, Pity, and Item Supply. We note, however, that in some cases Sato et al. describe the differences between loot box types using features that are not mutually exclusive-for example, their "consecutive" type of random procedure, in which the chances of receiving a rare reward are increased if the player triggers a set amount of RRMs through a bulk purchase (e.g., a package deal for ten consecutive RRMs, Batch Pulls in our model), can exist alongside their "step-up/stepdown" type (the equivalent of Pity > pull scaling in our model). Indeed, this is the case in Fire Emblem Heroes.

A few features of Sato et al.'s (2020) work are not represented here, however. These differences are largely a result of the fact that we chose to focus only on monetary transactions (i.e., not random rewards triggered

\footnotetext{
${ }^{1}$ Note that even these two features do not entirely capture loot box embeddedness, as players may sometimes cash out contents by selling their entire account. These transactions sometimes involve thousands of US dollars (g2g.com n.d.), but to our knowledge no research has been done on this.

${ }^{2}$ The example of reinvestment used in that paper, Clash Royale, is more accurately described as a game with free analogous loot boxes that may yield free virtual currency-premium loot boxes, on the other hand, do not contain the same currency used to purchase them (gems).
} 
by watching advertisements) and that we structured our model specifically around design features which might be expected to have a meaningful effect on player behavior. It is not clear, for example, that the difference between a "loot box" and "card pack" (two categories in Sato et al.'s audiovisual implementation taxon) is psychologically important.

Beyond those in the works above, most of the remaining features in LoBoF v0.1 have not been formally discussed or investigated in the academic literature. This includes a host of important features and categories related to rarity, handling of duplicates and undesirable items, pity systems, various types of teasers and free samples, duration, and more.

\section{LIMITATIONS}

As stated earlier, this model is inherently subjective, grounded in a constructivist view of knowledge, and should not be treated as conclusive. It merely represents one attempt to taxonomize the types of loot boxes with a particular pragmatic purpose; within this pragmatic purpose, we are limited by the lack of existing evidence about featural-level effects and in most cases can only speculate about possible effects on players. We re-emphasize that as evidence demonstrates the importance or unimportance of given features or categories-a line of research we hope to encourage with this work-these should be added or removed to the taxonomy in an ongoing process.

While we believe this work represents the most granular list of features in the academic literature to this point, it is also not exhaustive. This model does not include unmonetized gambling simulations, social casino games, and certain niche features that arose only in one game in our data (e.g., the possibility to receive no reward at all when remotely controlling a claw machine in Clawee). Some features or categories may only be found outside of English language games. Additionally, a host of non-loot box monetization strategies may be viewed by players as problematic (Petrovskaya and Zendle 2021), and there is no doubt that developers will continue to innovate in terms of both random and non-random monetization. One such notable development is the rise of crypto-games (Scholten et al. 2019). As existing features are identified or new ones implemented, this model should be updated accordingly.

A final limitation of this model, and taxonomies more generally, is that we have only described features that were identified as categorizable. This should not be interpreted as an indication that only these features might affect player behavior. Emerging evidence shows that a large range of nuanced and continuous design features, including the degree of competitive advantage/pay to win (von Meduna et al. 2020), the precise odds of receiving each item (Kwon 2020), and audiovisual components like "juiciness" (Kao 2020) are likely to have meaningful effects on player behavior, experience, and spending. Instead, we present these features as those that could feasibly be discretized.

\section{CONCLUSION}

In this paper, we developed LoBoF v0.1 as a first iteration of a featural model of loot box implementations. Across six domains of variation and thirty-two unique features, we show that the range of possible loot box designs is wider than previously appreciated. This intricacy creates challenges for both regulators and consumers, and we argue that solutions will need to be tailored to the video game sphere. Specifically, we suggest that gambling regulators may be currently ill-equipped to deal with this complexity, and that there may be a need for a more comprehensive source of information for consumers than content descriptors currently allow for. We point out the need for more high-quality research on how different types of loot boxes might affect players and call for increased industry collaboration to achieve this.

\section{ACKNOWLEDGEMENTS}

The authors would like to thank Harry Holmwood for valuable feedback on the feature list and player behavior rationale. 


\section{SUPPLEMENTARY MATERIALS AND DATA AVAILABILITY}

Complete descriptions of each feature and category can be found in the supplementary materials on the Open Science Framework; alongside this, readers can also find the source data (games with one or more loot box implementations) and details of the iterative taxonomizing process. Link: https://osf.io/emkyr.

\section{FUNDING}

This work was supported by the EPSRC Centre for Doctoral Training in Intelligent Games \& Games Intelligence (IGGI) [EP/S022325/1].

\section{LUDOGRAPHY}

To conserve space, citations for each of the example games are included in the supplementary materials, including evidence in the form of videos or other media for why each game was categorized as it was.

\section{BIBLIOGRAPHY}

Brock, T. and Johnson, M. 2020. "Gambling for Fashion: How Videogame Designers Capitalise on 'Status Ambivalence' within Videogame Play." Proceedings of DiGRA 2020, 1-3.

Cermak, D. 2020. "Micro-Transactions, Massive Headaches: International Regulation of Video Game Loot Boxes." Michigan State International Law Review 28 (2): 273-322.

Chase, H. W., and Clark, L. 2010. "Gambling Severity Predicts Midbrain Response to Near-Miss Outcomes." Journal of Neuroscience 30 (18): 6180-87. https://doi.org/10.1523/JNEUROSCI.575809.2010.

Committee of Advertising Practice. 2021. "Guidance on Advertising In-Game Purchases: Advertising Guidance (Broadcast and Non-Broadcast)." United Kingdom Advertising Standards Authority. https://www.asa.org.uk/resource/guidance-on-advertising-in-game-purchases.html.

Common Sense Media. n.d. "Common Sense Media Game Reviews." Accessed October 14, 2021. https://www.commonsensemedia.org/game-reviews.

De Neys, W., ed. 2018. Dual Process Theory 2.0. 1 Edition. Current Issues in Thinking and Reasoning. New York: Routledge, Taylor \& Francis Group.

Deans, E. G., Thomas, S. L., Daube, M. and Derevensky, J. 2016. "I Can Sit on the Beach and Punt through My Mobile Phone': The Influence of Physical and Online Environments on the Gambling Risk Behaviours of Young Men." Social Science \& Medicine 166 (October): 110-19. https://doi.org/10.1016/j.socscimed.2016.08.017.

Dixon, M. R. 2000. "Manipulating the Illusion of Control:Variations in Gambling as a Function of Perceived Control Over Chance Outcomes." The Psychological Record 50 (4): 705-19. https://doi.org/10.1007/BF03395379.

Entertainment Software Ratings Board. n.d. "ESRB Ratings Guide.” Accessed October 14, 2021. https://www.esrb.org/ratings-guide/.

g2g.com. n.d. "WOW Accounts for Sale (US)." Accessed October 14, 2021. https://www.g2g.com/wowus/account-2299-19409.

“Gaming or Gambling?" 2018. Nature Human Behaviour 2 (8): 525-525. https://doi.org/10.1038/s41562018-0369-5.

Hamari, J. and Lehdonvirta, V. 2010. "Game Design as Marketing: How Game Mechanics Create Demand for Virtual Goods." International Journal of Business Science \& Applied Management 5 (1): 14-29.

Hedström, P. and Swedberg, R., eds. 1998. Social Mechanisms: An Analytical Approach to Social Theory. Studies in Rationality and Social Change. Cambridge: New York: Cambridge University Press.

Heidhues, P. and Koszegi, B. 2004. "The Impact of Consumer Loss Aversion on Pricing." SSRN Electronic Journal. https://doi.org/10.2139/ssrn.658002.

"IEEE Xplore Abstract Record." n.d. Accessed November 16, 2020. https://ieeexplore.ieee.org/document/8698799?arnumber=8698799. 
Johannes, N., Vuorre M., and Przybylski A K. 2021. "Video Game Play Is Positively Correlated with WellBeing." Royal Society Open Science 8 (2): $r$ rsos.202049, 202049. https://doi.org/10.1098/rsos.202049.

Marco, J, and Tanaka, E. 2017. "Game of Chance Elements in Free-to-Play Mobile Games. A Freemium Business Model Monetization Tool in Need of Self-Regulation?" In , 1-19. Passau, Germany: International Telecommunications Society. https://ideas.repec.org/p/zbw/itse17/169473.html.

Kanspelautoriteit (Netherlands Gambling Authority). 2018. "Study into Loot Boxes A Treasure or a Burden?" $\quad$ https://www.kansspelautoriteit.nl/publish/library/6/study into loot boxes a treasure or a burden - eng.pdf.

Kansspelcommissie (Belgian Gaming Commission). 2018. "Loot Boxen in Drie Videogames in Strijd Met Kansspelwetgeving." $\quad$ https://www.koengeens.be/news/2018/04/25/loot-boxen-in-drievideogames-in-strijd-met-kansspelwetgeving.

Kao, D. 2020. "Infinite Loot Box: A Platform for Simulating Video Game Loot Boxes." IEEE Transactions on Games 12 (2): 219-24. https://doi.org/10.1109/TG.2019.2913320.

Kassinove, J. I., and Schare, M. L. 2001. "Effects of the 'near Miss' and the 'Big Win' on Persistence at Slot Machine Gambling." Psychology of Addictive Behaviors 15 (2): 155-58. https://doi.org/10.1037/0893-164X.15.2.155.

King, D. L., Delfabbro P. H., Derevensky, J. L, and Griffiths, M. D. 2012. "A Review of Australian Classification Practices for Commercial Video Games Featuring Simulated Gambling." International Gambling Studies 12 (2): 231-42. https://doi.org/10.1080/14459795.2012.661444.

Kristiansen, S. and Severin, M. C. 2020. "Loot Box Engagement and Problem Gambling among Adolescent Gamers: Findings from a National Survey." Addictive Behaviors 103 (April): 106254. https://doi.org/10.1016/j.addbeh.2019.106254.

Kukla, A. 2000. Social Constructivism and the Philosophy of Science. Philosophical Issues in Science. London; New York: Routledge.

Kwon, O. C. 2020. "Agent-Based Simulation of the Effect of Probability Manipulations on Loot Box Markets." Master's thesis, Seoul: Seoul National University. http://sspace.snu.ac.kr/bitstream/10371/169406/1/000000162404.pdf.

Leino, T., Torsheim, T., Pallesen, S., Blaszczynski, A., Sagoe, D. and Molde, H. 2016. "An Empirical RealWorld Study of Losses Disguised as Wins in Electronic Gaming Machines." International Gambling Studies 16 (3): 470-80. https://doi.org/10.1080/14459795.2016.1232433.

Lewis, C. 2014. Irresistible Apps: Motivational Design Patterns for Apps, Games, and Web Based Communities. New York: Apress.

Li, E., Rockloff, M. J., Browne, M. and Donaldson, P. 2016. "Jackpot Structural Features: Rollover Effect and Goal-Gradient Effect in EGM Gambling.” Journal of Gambling Studies 32 (2): 707-20. https://doi.org/10.1007/s10899-015-9557-7.

Madigan, J. 2016. Getting Gamers: The Psychology of Video Games and Their Impact on the People Who Play Them. Lanham, Maryland: Rowman \& Littlefield.

McBride, J. and Derevensky, J. 2009. "Internet Gambling Behavior in a Sample of Online Gamblers." International Journal of Mental Health and Addiction 7 (1): 149-67. https://doi.org/10.1007/s11469008-9169-x.

Monaghan, S. and Blaszczynski, A. 2009. "Electronic Gaming Machine Warning Messages: Information versus Self-Evaluation." The Journal of Psychology 144 (1): 83-96. https://doi.org/10.1080/00223980903356081.

Murch, W. S. and Clark, L. 2019. "Effects of Bet Size and Multi-Line Play on Immersion and Respiratory Sinus Arrhythmia during Electronic Gaming Machine Use." Addictive Behaviors 88 (January): 6772. https://doi.org/10.1016/j.addbeh.2018.08.014.

Nickerson, R. C., Varshney, U., and Muntermann, J. 2013. "A Method for Taxonomy Development and Its Application in Information Systems." European Journal of Information Systems 22 (3): 336-59. https://doi.org/10.1057/ejis.2012.26. 
Nielsen, R. K. L. and Grabarczyk, P. 2018. "Are Loot Boxes Gambling? Random Reward Mechanisms in Video Games." In Proceedings of DiGRA 2018, 20. https://doi.org/10.26503/todigra.v4i3.104.

Pan European Game Information. n.d. "PEGI Age Labels." Accessed October 14, 2021. https://pegi.info/what-do-the-labels-mean.

Petrovskaya, E., and Zendle, D. 2021. "Predatory Monetisation? A Categorisation of Unfair, Misleading, and Aggressive Monetisation Techniques in Digital Games from the Perspective of Players." Preprint. PsyArXiv. https://doi.org/10.31234/osf.io/cdwhq.

Przybylski, A. K., Rigby, C. S., and Ryan, R. M. 2010. "A Motivational Model of Video Game Engagement." Review of General Psychology 14 (2): 154-66. https://doi.org/10.1037/A0019440.

Saldaña, Johnny. 2016. The Coding Manual for Qualitative Researchers. 3E [Third edition]. Los Angeles; London: SAGE.

Sato, Y., Brückner, S., Kurabayashi, S. and Waragai, I. 2020. "An Empirical Taxonomy of Monetized Random Reward Mechanisms in Games." In Proceedings of DiGRA 2020, 21.

Scholten, O. J., Hughes, N. G. J., Deterding, S., Drachen, A., Walker, J. A. and Zendle, D 2019. "Ethereum Crypto-Games: Mechanics, Prevalence, and Gambling Similarities." In Proceedings of the Annual Symposium on Computer-Human Interaction in Play, 379-89. Barcelona Spain: ACM. https://doi.org/10.1145/3311350.3347178.

Sprott, D. E., Hardesty, D. M. and Miyazaki, A. D. 1998. "Disclosure of Odds Information: An Experimental Investigation of Odds Format and Numeric Complexity." Journal of Public Policy \& Marketing 17 (1): 11-23.

Starcke, K., Antons, S., Trotzke, P. and Brand, M. 2018. "Cue-Reactivity in Behavioral Addictions: A MetaAnalysis and Methodological Considerations." Journal of Behavioral Addictions 7 (2): 227-38. https://doi.org/10.1556/2006.7.2018.39.

Suhr, J. A. and Tsanadis, J. 2007. "Affect and Personality Correlates of the lowa Gambling Task." Personality and Individual Differences 43 (1): 27-36. https://doi.org/10.1016/j.paid.2006.11.004.

Thaler, R. 1980. "Toward a Positive Theory of Consumer Choice." Journal of Economic Behavior \& Organization 1 (1): 39-60. https://doi.org/10.1016/0167-2681(80)90051-7.

Tondello, G. F., Arrambide, K., Ribeiro, G., Cen, A. J. L. and Nacke, L. E. 2019. "II Don't Fit into a Single Type': A Trait Model and Scale of Game Playing Preferences." In Human-Computer Interaction INTERACT 2019, edited by David Lamas, Fernando Loizides, Lennart Nacke, Helen Petrie, Marco Winckler, and Panayiotis Zaphiris, 11747:375-95. Cham: Springer International Publishing. https://doi.org/10.1007/978-3-030-29384-0 23.

Tregel, T., Schwab, M. C., Nguyen, T. T. L., Müller, P. N. and Göbel, S. 2020. "Costs to Compete - Analyzing Pay to Win Aspects in Current Games." In Joint International Conference on Serious Games, edited by Minhua Ma, Bobbie Fletcher, Stefan Göbel, Jannicke Baalsrud Hauge, and Tim Marsh, 12434:177-92. Lecture Notes in Computer Science. Cham: Springer International Publishing. https://doi.org/10.1007/978-3-030-61814-8 14.

Veblen, T. 1899. The Theory of the Leisure Class: An Economic Study of Institutions. New York: The Macmillan Company.

Von Meduna, M., Steinmetz, F., Ante, L., Reynolds J. and Fiedler, I. 2020. "Loot Boxes Are Gambling-like Elements in Video Games with Harmful Potential: Results from a Large-Scale Population Survey." Technology in Society 63 (November): 101395. https://doi.org/10.1016/j.techsoc.2020.101395.

Wang, Y. and Mainwaring, S. D. 2008. "Human-Currency Interaction: Learning from Virtual Currency Use in China." In Proceeding of the Twenty-Sixth Annual CHI Conference on Human Factors in Computing Systems - CHI '08, 25. Florence, Italy: ACM Press. https://doi.org/10.1145/1357054.1357059.

Xiao, L. Y. 2020. "Which Implementations of Loot Boxes Constitute Gambling? A UK Legal Perspective on the Potential Harms of Random Reward Mechanisms." International Journal of Mental Health and Addiction, August. https://doi.org/10.1007/s11469-020-00372-3. 
Xiao, L. Y., Henderson, L. L. and Newall, P. W. S. 2021. "What Are the Odds? Lower Compliance with Western Loot Box Probability Disclosure Industry Self-Regulation than Chinese Legal Regulation." Preprint. Open Science Framework. https://doi.org/10.31219/osf.io/g5wd9.

Yee, N. 2006. "Motivations for Play in Online Games." CyberPsychology \& Behavior 9 (6): 772-75. https://doi.org/10.1089/CPB.2006.9.772.

Zendle, D. 2019. "Problem Gamblers Spend Less Money When Loot Boxes Are Removed from a Game: A before and after Study of Heroes of the Storm." PeerJ 7 (October): e7700. https://doi.org/10.7717/peerj.7700.

Zendle, D. and Cairns, P. 2018. "Video Game Loot Boxes Are Linked to Problem Gambling: Results of a Large-Scale Survey." PLoS One 13 (11): e0206767. https://doi.org/10.1371/journal.pone.0206767.

Zendle, D., Cairns, P., Barnett, H. and McCall, C. 2020. "Paying for Loot Boxes Is Linked to Problem Gambling, Regardless of Specific Features like Cash-out and Pay-to-Win." Computers in Human Behavior 102 (January): 181-91. https://doi.org/10.1016/j.chb.2019.07.003.

Zendle, D., Meyer, R. and Over, H. 2019. "Adolescents and Loot Boxes: Links with Problem Gambling and Motivations for Purchase." Royal Society Open Science 6 (6): 190049. https://doi.org/10.1098/rsos.190049.

Zendle, D., Meyer, R., Waters, S., Ballou, N. and Cairns, P. 2020. "The Prevalence of Loot Boxes in Mobile and Desktop Games." Addiction. https://doi.org/10.1111/add.14973.

Zendle, D., Petrovskaya, E. and Wardle, H. 2020. "How Do Loot Boxes Make Money? An Analysis of a Very Large Dataset of Real Chinese CSGO Loot Box Openings." Preprint. PsyArXiv. https://doi.org/10.31234/osf.io/5k2sy. 